\title{
Grammatical gender in the discourse of multilingual children's acquisition of German*
}

\author{
Elke Montanari (Hildesheim)
}

\begin{abstract}
The acquisition of grammatical gender by multilingual pre-school children (aged six) was investigated by observing their narration and discourse. It emerged that only three of the 17 children actually used gender to classify nouns. Grammatical agreement is acknowledged as a key feature of gender acquisition, and it reflects developmental steps. Children growing up with mostly bilingual German input at a low proficiency level had the greatest difficulties in acquiring gender and agreement in the group investigated.
\end{abstract}

\section{$1 \quad$ Introduction}

\subsection{Grammatical gender}

In the original definition by Hockett (1958), gender is described as a classification of nouns that affects other words (in German, for example, it affects the article). It also classifies all nouns and is unambiguous for nearly all of them (cf. Hockett 1958: 231). This notion has been explored from many different angles (e. g., Corbett 1991; Franceschina 2005). ${ }^{1}$ The following definitions share a number of main characteristics; however, they differ according to whether they perceive gender as a classification (cf. Hockett 1958) or as a system (cf. Matthews 1997), and whether they regard the relationship between nouns and gender-marking lexemes as association (cf. Hockett 1958), agreement (cf. Corbett 1991) or syntactical

\footnotetext{
* This study was enabled by the Culture and Education Ministries of Hessen and Rheinland-Pfalz, Germany, and the Ludwig-Maximilians-University, Munich. The statistics were computed by Markus Schmitt at the Institute of Psychology, University of Education Heidelberg.

${ }^{1}$ These diverse reflections can be translated into a composite definition (Franceschina 2005: 78):

Composite definition of grammatical gender:

a) Genders are classes of nouns that result from the partitioning of the lexicon into nominal classes;

b) Nouns are gender triggers, and other categories marked for gender are targets;

c) Gender triggers and targets are structurally related;

d) Nouns in gender systems are exhaustively classified (in most cases this means inherently classified, but there are some exceptions);

e) The following categories can be gender targets: determiners, pronouns, quantifiers, numerals, possessives, adjectives, past and passive participles, verbs, adverbs, complementizers, adverbs, adpositions;

f) Gender assignment rules vary cross-linguistically;

g) The domain of gender agreement shows some cross-linguistic variation.
}

This definition summarises numerous features; however, the individual formulations are based on different theories and were developed to use them for specific investigative purposes. Point c., which investigated the structural relationship between gender triggers and targets, may be more expediently formulated if the type of relationship is indicated, e. g., "The triggers and targets of the gender marker are linked syntactically with one another." 
relations (cf. Matthews 1997). Concord is also used as a term to indicate the agreement of gender markings (for example, by Meisel 2011).

As a feature of the noun, gender contributes to the designating processes of the "Symbolfeld" (cf. Ehlich 1986) and is acquired as part of the basic semantic qualification (cf. id 2005). Furthermore, the gender of a noun is for some nouns part of the pattern within the phonological form, for example, nouns ending in -e being feminine, which means that phonological knowledge has to be activated (cf. Köpcke/Zubin 1984). Gender is also relevant in discourse: an essential function of gender is that it is discursive and assists by providing a reference. Reference is supported through agreement, a syntactic and discursive category. For these reasons, semantic, morpho-syntactic, phonological and discursive basic qualifications are involved in the application of gender in linguistic narration. Consequently, multiple linguistic characteristics have to be mentally processed at the same time. It follows, therefore, that gender production involves different cognitive capacities within a type of interface (cf. Hulk/Müller 2000; Serratrice/Sorace/Paoli 2004).

\subsection{Acquisition}

At the age of three, monolingual children acquiring gender languages are still exhibiting isolated errors in gender. By the age of five, however, they demonstrate no such uncertainty (cf. Mills 1985, 1986; Bewer 2004). An early sensibility to the phonological and morphological principles of gender assignment has been reported during the acquisition of various different languages (for German, see Mills 1986; Eisenbeiss 2003; for French, Karmiloff-Smith 1979; for Hebrew, Levy 1983; Berman 1985; for Spanish, Pérez-Pereira 1991; for Russian, Rodina/Westergaard 2012).

Gender is easily acquired in multilingual first language acquisition and is generally mastered by the age of three to three and a half (cf. Müller 2000). By the age of four, 90 per cent of the gender markings on articles are remarkably accurate, meaning that acquisition can be viewed as being unproblematic (cf. Müller et al. 2001): the same holds true for German-Italian.

In child second language (L2) acquisition, acquiring German gender appears to be a difficult and drawn-out process. Children whose first languages (L1s) are Russian or Turkish - and who arrive in Germany at the age of five or six - exhibit prolonged difficulties with gender (cf. Wegener 1995a, 1995b). The findings of long-term studies on Turkish-German children in Berlin reveal no improvements in gender marking (cf. Pfaff 2001) and demonstrate the long-term problem of acquisition (cf. Jeuk 2008).

Cornips/Hulk (2008) highlights a large margin between successful and less successful children in acquiring Dutch gender: children with multilingual simultaneous acquisition are much more successful at acquiring Dutch gender than children with Dutch as a second language in sequential acquisition. Hulk/Cornips (2006) assumes that input from parents who speak to their children in a second language that they themselves acquired later in life could contribute to gender uncertainty in children. Multiple interface domains are required to master gender. It is thus argued that interfaces are particularly vulnerable to variations in input quality (Hulk/Müller 2000; Serratrice/Sorace/Paoli 2004).

\section{Explanations}

Initial language contact. Differences between the acquisition of first and second languages involve the assumption of critical phases or sensitive windows at certain ages. It is assumed that sensitive phases exist for specific acquisition tasks (such as for the acquisition of phonological versus syntactical tasks, Meisel 2007). Specific development steps are performed particularly efficiently during these sensitive phases (cf. Bongaerts/Planken/Schils 
1995; Penner/Weissenborn 1996; Meisel 2007 among others). Language is also acquired after these phases, albeit requiring greater effort and with less success, with specific errors being made, at least in syntax/morphology. In order to differentiate between first and second language acquisition, Meisel (2007) suggests a threshold at around the age of four: if language contact starts at that age, then the acquisition is at the level of child L2 acquisition.

Special features of the German language. The homonymy of the German article and the lack of transparency in assignment principles are particularly difficult aspects of the German language (cf. Wegener 1995b). However, they cannot be the sole explanation for acquisition problems, otherwise these systematic acquisition obstacles would be also expected in first language acquisition.

The homonymy of gender markings on articles only exists in the isolated, context-free noun phrase; in discourse or in text, the gender markings are disambiguated by the abundance of information about semantic roles, case and number markings on the verb.

\subsection{German gender}

In German, a multitude of semantic and formal (phonological and morphological) assignment principles have been found (for example, Köpcke/Zubin 1984, summary; Eisenberg 2006). This profusion of assignment principles represents a major problem: it is often impossible to predict the correct gender with any certainty.

The main functions of gender lie in their contribution to reference in text and discourse; in supporting the organisation of the dictionary, and their syntactic parenthetical function in the noun phrase. Agreement in discourse extends beyond the confines of the sentence. Discourse between speakers of German who have a good mastery of the language contains continuous marking sequences that work together to allow for an (often unambiguous) determination of gender.

\subsection{Research questions}

This study used the concept of speech in a functional-pragmatic manner (cf. Redder 1987; Ehlich 2005; Rehbein/Meng 2007). Its objective was to gain insights into the difficulties specific to acquisition, and to understand precisely how this progresses in older children. To this end, the following research questions were formulated:

1) What is the level of gender acquisition in six-year-old children who have German as a second language compared to German-L1 children?

2) Are developmental stages observed or has fossilisation set in?

3) Are assignment principles being applied?

4) What is the impact of input quality?

Acquisition criteria were constructed in order to answer these questions. According to Hockett (1958), Corbett (1991) and Matthews (1997), gender is a noun classification requiring agreement markers on other words. It classifies all nouns, and, for the most part, definitively. The following criteria regarding gender acquisition are deduced from these definitions of gender, and form the basis for the subsequent evaluation of the data:

i. Noun classification: Speakers have recognised that nouns permanently belong to a class, and mark this class affiliation for most of the nouns. ${ }^{2}$

\footnotetext{
2 This does not concurrently mean that the noun is classified in the target gender class.
} 
ii. Target language classification: Gender is considered as being fully acquired when 90 per cent of the gender markings are accurate. ${ }^{3}$

iii. Agreement: Gender marking is used consistently.

iv. Differentiation: The target-language genders (in German: masculine, feminine and neuter) are differentiated (for German: in the singular form).

The criteria largely depend on one another and, to a certain extent, could appear to be circular; during evaluation, differentiation was shown to be expedient because this enabled acquisition phases to be determined separately.

\section{The study}

\subsection{Participants}

The children are multilingual, born in Germany, and do not suffer from pathological language disorders. The focus of this study was on children who were selected by their teachers to receive special language training (language support or prep courses). ${ }^{4}$ The evaluation by the educators was reviewed in the study using two testing procedures (HAVAS 5 (cf. Reich/Roth 2004), CITO (cf. Citogroup 2005)). Data was collected for ten girls and seven boys at two nursery schools and one primary school over a period of ten months. ${ }^{5}$

The study shows the diversity of multilingualism frequently found in educational institutions in Germany (cf. Gogolin/Reich 2001; Chlosta/Ostermann 2005) and other societies (e. g., Clyne/Kipp 2006). Seven of the 17 children are being brought up within a genderless language environment, namely Turkish or Kurdish Sorani. The other ten children are familiar with the concept of gender from their family language. None of the children have parents who speak German as their first language. Three children are being raised trilingually. Their data was analysed within the overall group (see Appendix for an overview).

The participants in the study have lived in Germany since birth (with the exception of one person who has been living in Germany since his/her first birthday). They live in multi-ethnic and multilingual residential areas in which German is the lingua franca: everyday life in this neighbourhood is conducted in German by people with other first languages.

All of the parents of the children observed speak German at a low learner level with the exception of Tomas' parents, who have achieved an intermediate level. This was established through interviews with the parents, in combination with self-assessment in the parent questionnaires. ${ }^{6}$ The survey and questionnaires showed that input can be classified on a continuum from predominantly first language to predominantly second language input.

\footnotetext{
3 For the classification to count as conforming with the target language, there must be an actual noun classification (see i.). Therefore, the first two criteria depend upon one another.

${ }^{4}$ Language support comprises a total of 80 hours (60 $\mathrm{min}$.); the children observed were divided into two groups of ten and eight children respectively and received two 90-minute sessions of language education per week at the nursery. The prep course consisted of 90 minutes per day of language education at the primary school. In a school year comprising 38 weeks, with some school days cancelled, around 350 lesson hours or 260 clock hours of special language tutoring were given.

5 All names have been changed.

${ }^{6}$ Language testing on the parents was not used. Their language proficiencies would have been more clearly attestable if a language test had been used. Parents were very cooperative in the interviews.
} 


\subsection{Method}

The investigation was carried out over a ten month period. In order to observe the impact of input quality, children with first language, second language and mixed input were included in the study. The children were observed within the group doing the language training activity and filmed with a video camera in spontaneous communication and dialogue situations. Additionally, narratives were collected for testing procedures (HAVAS 5). All of the recordings were transcribed using HIAT (cf. Ehlich/Rehbein 1976). The accumulated data consists of around 70 hours of audio and video recordings and 56 questionnaires completed by parents and children. The narratives and discourses for this analysis were extracted from recordings of the children. ${ }^{7}$

A type-token ratio was established so that the data could be compared: the individual gender markings on articles, anadeixis and deixis were recorded as tokens. Types were allotted if the same gender was assigned continuously to one noun - for example, if all markings for Maus (f) ${ }^{8}$, such as sie, ihr etc. consistently showed the same feminine gender. A type was also assigned if all of the markings in a discourse related to Maus were target-deviant and masculine. The criterion for a type was that a speaker used the same gender for a noun throughout a narrative/discourse with a maximum of one exception, and that it was referred to at least three times in different noun phrases. ${ }^{9}$ The relationship between tokens and types was determined by the agreement of the individual gender markings. If this was the case, then there were types; if not, there were only tokens.

\section{$3 \quad$ Results}

\subsection{Gender acquisition by multilingual children aged five to six and development steps}

Only one of the 17 children in the study group was able to exhibit types for every noun (criterion i) in its speech. ${ }^{10}$ Two children classified the majority of their nouns $(>80$ per cent). ${ }^{11}$ For four of the children, single types were observed in later recordings; some nouns were classified whilst others were not. Ten of the 17 children in total exhibited no noun classification.

\begin{tabular}{|l|l|l|l|l|}
\hline & $\begin{array}{l}\text { All the nouns } \\
\text { classified }\end{array}$ & $\begin{array}{l}\text { Majority of the nouns } \\
\text { classified }>80 \text { per } \\
\text { cent of nouns) }\end{array}$ & $\begin{array}{l}\text { Individual nouns } \\
\text { classified (2-8 } \\
\text { nouns) }\end{array}$ & $\begin{array}{l}\text { No classification } \\
\text { detected }\end{array}$ \\
\hline $\begin{array}{l}\text { Number of } \\
\text { speakers }\end{array}$ & 1 & 2 & 4 & 10 \\
\hline
\end{tabular}

\section{Table 1: Classification of nouns}

It is only when children classify that they mark gender in line with the definition (criterion ii). At the point of determining, classification that conformed to the target language made sense. This only applied to three children in the group. They all achieved scores of at least 80 per cent in target language classification.

\footnotetext{
7 It would have been very interesting to examine agreement within the noun phrase, for example when conjugating adjectives. Unfortunately, the children rarely used any adjectives in their sentences.

$8(\mathrm{f})=$ feminine,$(\mathrm{m})=$ masculine,$(\mathrm{n})=$ neuter.

${ }^{9}$ It was possible and, partially the case, that in one narrative one type (e. g. masculine) was exhibited and in a later narrative another (e. g., feminine) type was used.

10 See Appendix for types/tokens.

11 An overview can be found in the Appendix.
} 
Some children started to produce agreement during the observation period (criterion iii). They showed agreement over a few utterances, but not yet throughout the entire discourse. In this example, the girl (aged 6,212) used the same gender markings for the pre-noun article and the deixis, but only for adjacent utterances:

(T1) und da hat das der Tiger gehört.

(T2) Weil der war neben - Steine. ...

(T3) Und die Tiger hat gehüpft,

(T4) die wollt das Vogel.

The number of utterances in which children can exhibit agreement is a measurement of the progress of acquisition. Some children can only maintain agreement throughout two utterances whereas others can achieve five or more.

Some children showed agreement for discourse segments. Agreement markers were found throughout extended sequences of utterances. In the following excerpt (aged 5,9, another girl), they stretched over five (T26 et seqq.) and six (T25 et seqq.) utterances, all related to the same masculine noun. They alternated between only masculine (bold) and only feminine (italics).

(T5) Anna da seid er leise und geht er und geht er hier, und der singt und der fresst der...

(T6) Anna Die hat die noch gesehnt, und dann hat/wollt/und dann hat die hier leise, wollt die springen ...

The girl noticed that gender markings in discourse relate to one another; however, she had not yet understood their relationship. Three of the 17 children proceeded in this way and achieved agreement in discourse segments.

The overview below shows the children's acquisition stages:

\begin{tabular}{|l|l|}
\hline Acquisition & Children \\
\hline Acquired agreement with classification & 3 \\
\hline $\begin{array}{l}\text { Agreement throughout more than five utterances, no } \\
\text { classification }\end{array}$ & 2 \\
\hline Agreement in adjacent utterances, no classification & 3 \\
\hline Agreement in discourse segments, no classification & 3 \\
\hline Marking of only one gender paradigm ${ }^{13}$ & 3 \\
\hline No evidence of agreement & 3 \\
\hline
\end{tabular}

Table 2: Acquisition of agreement at the end of the observation period

None of the children used all three genders (criterion iv). Five children used gender markings of three genders; however, these were isolated events without classification. Some of the children only showed markers belonging to a single gender paradigm, for example, those related to the feminine gender.

\subsection{Input quality}

All of the children in this study have been in contact with the German language in their social environment from the first months of their life onwards. German is spoken to 15 of the 17 children within their family. Only two of the families report that the parents only use their first languages when with the children.

\footnotetext{
126 years, 2 months.

13 Over the entire period of observation.
} 


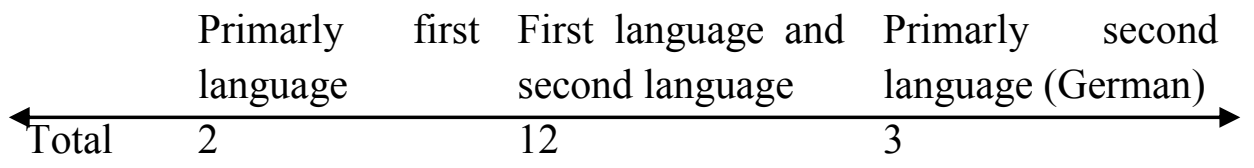

Table 3: Languages use within the family

The children who receive an input in the parents' native language are more advanced in the acquisition of gender than those with a German, non-native input from birth. Three children mainly receive their parents' learner-variety input. They receive second-language input in German from their parents. At the same time, they hear little or even no first language input from their parents. The children with the greatest difficulties in terms of agreement primarily have input of a learner variety and no or only limited input in their parents' first language.

In order to illustrate these patterns more clearly, the gender acquisition results were classified into four levels of acquisition. First, children with a complete level of acquisition were able to classify all nouns correctly (and with correct agreement) for more than 90 per cent of the time. They were also capable of distinguishing three genders. Second, those with an advanced level of acquisition were able to classify the majority of nouns correctly at least 80 per cent of time, but they only made a distinction between two genders; their use of agreement was correct more than 90 per cent of the time. Third, in the case of children with a threshold level of acquisition, there was neither classification of nouns nor any agreement in adjacent utterances; a distinction was made between two genders. Fourth, children with a low level of acquisition exhibited neither classification, nor agreement, nor function marking.

\begin{tabular}{|l|l|l|l|l|}
\hline Level & L1 (+gender) & $\begin{array}{l}\text { L2 (+gender) and } \\
\text { L2 German }\end{array}$ & $\begin{array}{l}\text { L1 (-gender) and } \\
\text { L2 German }\end{array}$ & L2 German \\
\hline Complete & & & & \\
\hline Advanced & 2 & 1 & & 1 \\
\hline Threshold & 5 & 3 & 2 \\
\hline Low & & 1 & 2 & \\
\hline
\end{tabular}

Table 4: Overview of acquisition

Contrary to the findings of Müller (2000) and Bewer (2004), the research showed that children who grow up bilingually and with German input from birth also have difficulties. Input quality is considered as one contributor to the different findings here. This study examines children in low-level second-language input circumstances, whereas previous studies investigated constellations with double first-language input (OPOL). ${ }^{14}$

It is necessary to differentiate between the "native language of the person raising the children, their second languages and their language blends" (Rehbein/Grießhaber 1996: 68). In the first case, children can draw on the first language as the basis for acquisition. Hence, they possess an acquired language (first-language input) of native-speaker quality. In the second case, the children base their acquisition on a learner variety (learner input or non-native input, see also van den Bogaerde/Knoors/Verrips 199415). This distinction is particularly relevant to the assumption that learner varieties, especially when at a low level, are structurally different from fully acquired languages (cf. Klein 1997; Ahrenholz 2005; Hendriks 2005). An input at a low level of mastery (level A of the CERF) may have adverse effects, whilst an intermediate language level does not seem to be as detrimental to acquisition (see Saunders 1988).

\footnotetext{
14 According to the principle of "one person one language".

${ }^{15}$ Here the acquisition of sign language by hearing-impaired children with hearing parents is described. In these cases, the parents' L2 usually forms the basis of the child's L1 acquisition.
} 


\subsection{Language influence}

The three children who could classify and whose gender acquisition is most well developed speak gender languages (Panjabi/Urdu, Polish, Albanian). None of the children whose family language is genderless are able to classify. Among the five children with the greatest difficulties, three of the children speak gender languages in their families. Hence, the assumption that gender existence in the first language has a strong positive impact on gender acquisition in a second language is weakened.

\section{Discussion}

\subsection{Consequences}

Educationally, it is only on seldom occasions, such as when a family enters the country, that there can be a strict and clear distinction between simultaneous and sequential acquisition. For the majority of the children, as is the case in this study, contact with the language environment - in this case German - and one or more other languages occurs from birth onwards.

In families with a migration background, the parents' second language remains the means of communication (cf. Clyne/Kipp 2006). Instead of second language acquisition, the majority of the children experience multilingual (simultaneous) acquisition with a learner variety input of German. Hence, it can be assumed that there is a necessary input minimum (cf. Meisel 2011) ${ }^{16}$, and that some children have experienced input below the minimal threshold.

Gender acquisition in children with German as a second language will not have been mastered by the age of six. The fact that 14 out of the 17 children do not classify nouns one year before starting school, and that none of the children assign gender, shows that there are considerable, long-lasting challenges involved in acquiring gender. However, important stages in gender and agreement acquisition can be observed. The interim stages of gender acquisition are found in the gradual development of agreement in discourse. These agreement chains are consistently developed over long series of utterances.

\subsection{Gender acquisition: function}

Gender acquisition means coming to terms with agreement; those children who have mastered agreement achieve high levels of accuracy in gender markings. Hence, I support a communication-based understanding of gender acquisition. This orients children towards one of the most important functions of gender in communication, namely, to support reference and cohesion. Acquiring gender means more than acquiring a lexical feature. It is a linguistic tool that enables actions to be successfully connected and implemented. Gender acquisition skills need to be supported through discoursive, syntactic and phonological information.

Such a functionally oriented perspective provides an insight into the way a non-transparent grammatical gender system can give clear indications. Many gender markings referring to the same noun reveal the noun's gender when brought together in discourse. Even though a single marking, such as ein $(\mathrm{m} / \mathrm{n})$, often does not give an unequivocal indication of the noun's gender, the gender of the noun becomes clear when considered in conjunction with multiple nominal phrases within a discourse or text. It is often unambiguous, or at least gender possibilities are reduced. In discourse, children and learners receive clear, transparent, reliable and recurring markers. Children can decode gender markings in discourse to the level of their language acquisition process. Consequently, they are able to process longer, discursive passages, and are able to master case. Thus, children who still have problems with agreement

\footnotetext{
16 In his terminology, primary linguistic data.
} 
are unable to assign gender correctly to very frequent nouns such as Mädchen, Teller, or Auto (cf. Wegener 1995a). These children are unable to connect gender markers due to their lack of experience with agreement; this is not due to the infrequency of the noun. They fail to realise that sie and die can refer to the same noun and are members of one gender paradigm.

\subsection{Input quality}

Input quality proves to be a crucial factor in acquisition. Successful acquisition is not only determined by whether a language is offered as a stimulus and for how long such a stimulus was available, the success of (at least gender) acquisition is also dependent on whether such stimuli were available at a native or less fluent level which is the case in some learner varieties during the language acquisition process. Parents should therefore be encouraged to use their native tongue within the family, to strengthen it through reading and other methods of encouragement and, additionally - rather than alternatively - to seek equally qualified German language support for their children.

\section{References}

Ahrenholz, Bernt (2005): "Reference to persons and objects in the function of subject in learner varieties". In: Hendriks, Henriette (ed.): The structure of learner varieties. Berlin, de Gruyter: 19-64.

Berman, Ruth A. (1985): "The acquisition of Hebrew". In: Slobin, Dan I. (ed.): The crosslinguistic study of language acquisition. Hillsdale, NJ, Lawrence Erlbaum: 255-371.

Bewer, Franziska (2004): "Der Erwerb des Artikels als Genus-Anzeiger im deutschen Erstspracherwerb". ZAS Papers in Linguistics 33: 87-140.

Bongaerts, Theo/Planken, Brigitte/Schils, Erik (1995): "Can late learners attain a native accent in a foreign language? A test of the critical period hypothesis". In: Singleton, David M./Lengyel, Zsolt (eds.): The age factor. Second language acquisition. Clevedon, Multilingual Matters: 30-50.

Chlosta, Christoph/Ostermann, Torsten (2005): "Warum fragt man nach der Herkunft, wenn man Sprache meint? Ein Plädoyer für eine Aufnahme sprachbezogener Fragen in demographische Untersuchungen". In: Bundesministerium für Bildung und Forschung (BMBF). Referat Öffentlichkeitsarbeit (ed.): Migrationshintergrund von Kindern und Jugendlichen. Wege zur Weiterentwicklung der amtlichen Statistik. Berlin, BMBF: 55-66.

Citogroup (ed.) (2005): Cito Sprachtest. Butzbach: Cito Deutschland.

Clyne, Michael/Kipp, Sandra (2006): Tiles in a multilingual mosaic. Macedonian, Filipino and Somali in Melbourne. Canberra, Australa: Australian National University.

Corbett, Greville G. (1991): Gender. Cambridge: Cambridge University Press.

Cornips, Leonie/Hulk, Aafke (2008): "Factors of success and failure in the acquisition of grammatical gender in dutch". Second Language Research 24: 267-295.

Ehlich, Konrad (1986): "Funktional-pragmatische Kommunikationsanalyse. Ziele und Verfahren". In: Hartung, Wolfdietrich (ed.): Untersuchungen zur Kommunikation Ergebnisse und Perspektiven. Internationale Arbeitstagung in Bad Stuer. Berlin: Akademie der Wissenschaften der DDR, Zentralinstitut für Sprachwissenschaft: 15-40.

Ehlich, Konrad (2005): "Eine Expertise zu 'Anforderungen an Verfahren der regelmäßigen Sprachstandsfeststellung als Grundlage für die frühe und individuelle Sprachförderung von Kindern mit und ohne Migrationshintergrund"'. In: Gogolin, Ingrid/Neumann, Ursula/Roth, Hans-Joachim (eds.): Sprachdiagnostik bei Kindern und Jugendlichen mit Migrationshintergrund. Münster, Waxmann: 33-50.

Ehlich, Konrad/Rehbein, Jochen (1976): "Halbinterpretative Arbeitstranskriptionen (HIAT)". Linguistische Berichte 45: 21-41.

Eisenbeiss, Sonja (2003): Merkmalsgesteuerter Grammatikerwerb. Eine Untersuchung zum Erwerb der Struktur und Flexion von Nominalphrasen. Universität Düsseldorf. 
Dissertation. http://www.researchgate.net/publication/29747420_Merkmalsgesteuerter Grammatikerwerb_Eine_Untersuchung_zum_Erwerb_der_Struktur_und_Flexion_von_No minalphrasen, accessed March 5, 2014.

Eisenberg, Peter (2006): Das Wort. Grundriss der deutschen Grammatik. Stuttgart: Metzler. Franceschina, Florencia (2005): Fossilized second language grammars. The acquisition of grammatical gender. Amsterdam: Benjamins.

Gogolin, Ingrid/Reich, Hans H. (2001): "Immigrant languages in Federal Germany". In: Extra, Guus/Gorter, Durk (eds.): The other languages of Europe. Demographic, sociolinguistic and educational perspectives. Clevedon, Multilingual Matters: 193-214.

Hendriks, Henriette (ed.) (2005): The structure of learner varieties. Berlin: de Gruyter.

Hockett, Charles F. (1958): A course in modern linguistics. New York: Holt/Rinehart and Winston.

Hulk, Aafke/Cornips, Leonie (2006): "Between 2L1 and child L2-acquisition of Dutch. An experimental study of bilingual Dutch". In: Lleó, Concita (ed.): Interfaces in multilingualism. acquisition and representation. Amsterdam, Benjamins: 115-138.

Hulk, Aafke/Müller, Natascha (2000): "Crosslinguistic influence at the interface between syntactics and pragmatics". Bilingualism: Language and Cognition 3/3: 227-244.

Jeuk, Stefan (2008): "'Der Katze jagt den Vogel.' Aspekte von Genus und Kasus im Grundschulalter". In: Ahrenholz, Bernt (ed.): Zweitspracherwerb. Diagnosen, Verläufe, Voraussetzungen. Freiburg, Fillibach: 135-150.

Karmiloff-Smith, Annette (1979): A functional approach to child language. A study of determiners and reference. Cambridge: Cambridge University Press.

Klein, Wolfgang (1997): "Leaner varieties are the normal case". The Clarion. Magazine of European Second Language Association 3/1: 4-6.

Köpcke, Klaus-Michael/Zubin, David A. (1984): "Sechs Prinzipien für die Genuszuweisung im Deutschen. Ein Beitrag zur natürlichen Klassifikation". Linguistische Berichte 93: 2650.

Levy, Yonata (1983): "It's frogs all the way down". Cognition 15: 75-93.

Matthews, Peter H. (1997): The concise Oxford dictionary of linguistics. Oxford: Oxford University Press.

Meisel, Jürgen M. (2007): Exploring the limits of the LAD. A collection of four papers. Hamburg: Universität. (=Arbeiten zur Mehrsprachigkeit).

Meisel, Jürgen M. (2011): "Bilingual language acquisition and theories of diachronic change. Bilingualism as cause and effect of grammatical change". Bilingualism: Language and Cognition 14: 121-145.

Mills, Anne E. (1985): "The acquisition of German". In: Slobin, Dan I. (ed.): The crosslinguistic study of language acquisition. Hillsdale, NJ, Lawrence Erlbaum: 141-254.

Mills, Anne E. (1986): The acquisition of gender. Berlin: Springer.

Müller, Natascha (2000): "Gender and number in acquisition". In: Unterbeck, Barbara et al. (eds.): Gender in grammar and cognition. Berlin, de Gruyter: 351-400.

Müller, Natascha et al. (2001): "Das mehrsprachige Kind. Italienisch-Deutsch". Arbeiten zur Mehrsprachigkeit 16: 1-42.

Penner, Zvi/Weissenborn, Jürgen (1996): "Strong continuity, parameter setting and the trigger hierarchy. On the acquisition of the DP in Bernese Swiss German and High German". In: Clahsen, Harald (ed.): Generative perspectives on language acquisition. Empirical findings, theoretical considerations, crosslinguistic comparisons. Amsterdam, Benjamins: 161-200.

Pérez-Pereira, Miguel (1991): "The acquisition of gender. What Spanish children tell us". Journal of Child Language 18: 571-559. 
Pfaff, Carol W. (2001): "The development of co-constructed narratives by Turkish children in Germany". In: Verhoeven, Ludo/Strömqvist, Sven (eds.): Narrative development in a multilingual context. Amsterdam, Benjamins: 153-188.

Redder, Angelika (1987): "Modalverben im kindlichen Diskurs. Überlegungen zu ihrer Aneignung". In: Wagner, Klaus (ed.): Wortschatzerwerb. Bern, Lang: 30-58.

Rehbein, Jochen/Grießhaber, Wilhelm (1996): "L2-Erwerb versus L1-Erwerb. Methodologische Aspekte ihrer Erforschung". In: Ehlich, Konrad (ed.): Kindliche Sprachentwicklung. Konzepte und Empirie. Opladen, Westdeutscher Verlag: 67-120.

Rehbein, Jochen/Meng, Katharina (2007): "Kindliche Kommunikation als Gegenstand wissenschaftlicher Forschung (Einleitung)". In: Meng, Katharina/Rehbein, Jochen (eds.): Kindliche Kommunikation - einsprachig und mehrsprachig. Münster, Waxmann: 1-39.

Reich, Hans H./Roth, Hans-Joachim (2004): HAVAS 5 - Hamburger Verfahren zur Analyse des Sprachstandes bei 5-Jährigen. Hamburg: Behörde für Bildung und Sport.

Rodina, Yulia/Westergaard, Marit (2012): "A cue-based approach to the acquisition of grammatical gender in Russian". Journal of Child Language 39/5: 1077-1106.

Saunders, George (1988): Bilingual children. From birth to teens. Clevedon: Multilingual Matters.

Serratrice, Ludovica/Sorace, Antonella/Paoli, Sandra (2004): "Cross-linguistic influence at the syntax-pragmatics interface. Subjects and objects in English-Italian bilingual and monolingual acquisition". Bilingualism: Language and Cognition 10: 225-238.

Van den Bogaerde, Beppie/Knoors, Harry/Verrips, Maaike (1994): Language acquisition with non-native input. Amsterdam: Universiteit.

Wegener, Heide (1995a): Die Nominalflexion des Deutschen - verstanden als Lerngegenstand. Tübingen: Niemeyer.

Wegener, Heide (1995b): "Das Genus im DaZ-Erwerb. Beobachtungen an Kindern aus Polen, Russland und der Türkei". In: Handwerker, Brigitte (ed.): Fremde Sprache Deutsch. Grammatische Beschreibung - Erwerbsverläufe - Lehrmethodik. Tübingen, Narr: 1-24. 


\section{Appendix}

\begin{tabular}{|llllll|}
\hline Language & Language & Language & Alias & Sex & Age \\
\hline Albanian & German & Mariana & F & $6,3-7,017$ \\
Albanian & German & & Elena & F & $6,0-6,9$ \\
English & German & & Isabella & F & $5,4-6,1$ \\
Croatian & German & & Ilaria & F & $5,7-6,4$ \\
Kurdish Kurmanjî & German & Ülkü & F & $5,5-6,2$ \\
Kurdish Sorani & German & & Anna & F & $5,0-5,9$ \\
Kurdish Sorani & German & & Kira & F & $5,11-6,8$ \\
Panjabi & Urdu & German & Boris & M & $5,7-6,4$ \\
Polish & German & & Tomas & M & $5,8-6,5$ \\
Romanes Lovara & German & & Michael & M & $6,3-7,0$ \\
Serbian & German & & Anastasia & F & $5,4-6,1$ \\
Sicilian & German & Italian & Antonio & M & $5,3-6,0$ \\
Turkish & German & & Mehmet & M & $5,4-6,1$ \\
Turkish & German & & Ayse & F & $5,11-6,8$ \\
Turkish & German & & Sina & F & $5,4-6,1$ \\
Turkish & German & Pashto & Jo & M & $6,3-7,0$ \\
Turkish & German & & Ali & M & $5,4-6,1$ \\
\hline
\end{tabular}

Table 5: Languages spoken in the family, sex, age

17 The age 6,3 means: 6 years and three full months. 